International Journal of Linguistics, Literature and Translation

ISSN: 2617-0299 (Online); ISSN: 2708-0099 (Print)

DOI: 10.32996/ijltt

Journal Homepage: www.al-kindipublisher.com/index.php/ijltt

\title{
Legitimizing Racism: Critical Discourse Analysis of White Supremacy in Trump's Political Speeches
}

\author{
Ahmad Kareem Salem ${ }^{1} 8(D) \square$, Narmeen Abbas Lutfi' 8 (D) and Abbas Lutfi Hussein ${ }^{3}$ (D) \\ ${ }^{1}$ College of Arts, Iraqia Univiversity, Iraq \\ ${ }^{2}$ College of Arts, Imam Ja'far Al-Sadiq University, Iraq \\ ${ }^{3}$ College of Arts, Mustansiriyah University "I Iraq
}

$\triangle$ Corresponding Author: Ahmad Kareem Salem, E-mail: Ahmad.alsalim3434@yahoo.com

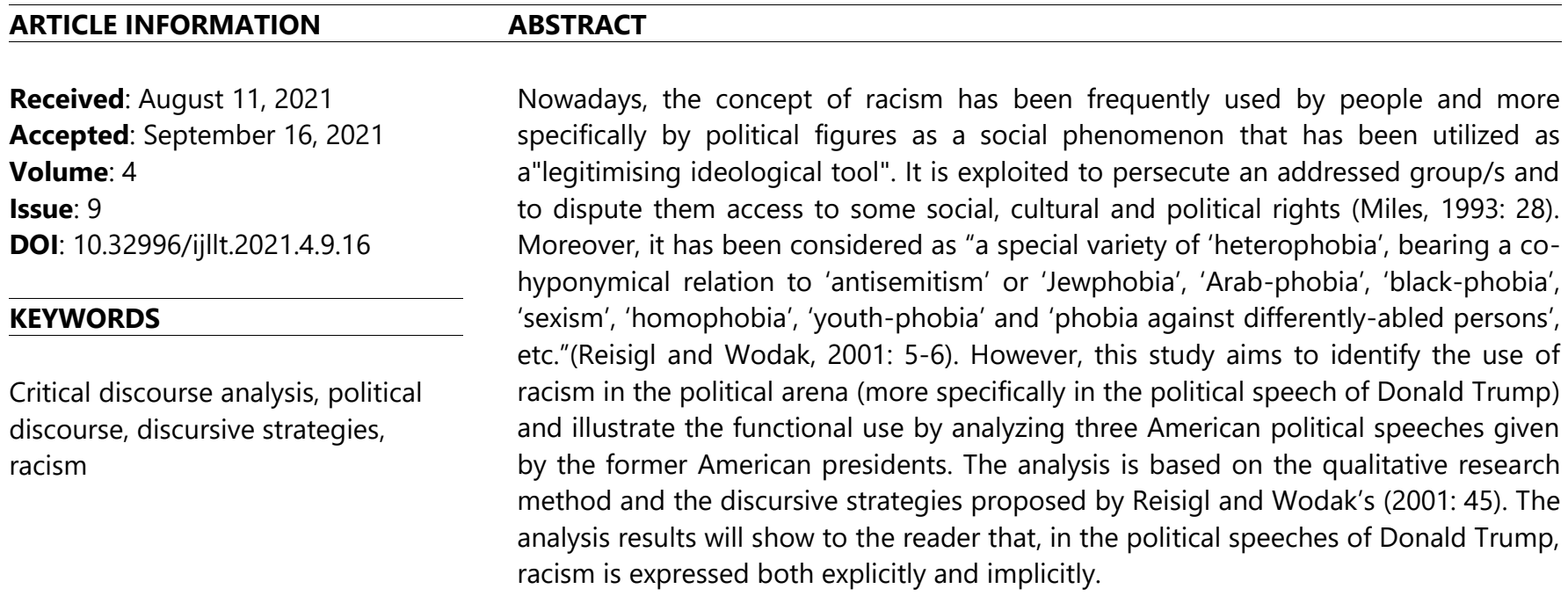

\section{Introduction}

The use of language for various purposes seems to be "governed by the conditions of society". However, these conditions govern the language user's access to and control their communicative means. Our communication with others occurs through a certain means and that means is the language. Hence, communication forms the purpose of language people use. Yet, more strikingly, language which relates to politics has power and control (Oliver, 1994:4). To understand the "symbolic system and codes of language will be insufficient"; to understand the language, therefore, is to take it as a discourse or a series of discourses.

Political language represents a variety of language and this variety has its unique features: syntactic, semantic, pragmatic, etc., each is expected to have a determining stylistic function, a case that makes it a definite register. While the fact that "politicians use verbal impact to control and affect others, written texts, on the other hand, seem to lack all these features". Therefore, written texts can be seen as forced to express meaning "lexically and syntactically" (Crystal, 1995: 291).

Like Oliver (1994: 3-7), scholars consider language not only as "a system of symbols or codes but also as a discourse". When it comes to discourse, we might think immediately of politics. Therefore, language becomes an instrument of politics and of control. Recently, politics can be viewed as "percolating almost each and every aspect of human thought" and activities to an enormous extent. In all of our societies, politicians and politics itself ruled us from democratic on one side and dictatorship from the other side (Newmark, 1986: 43).

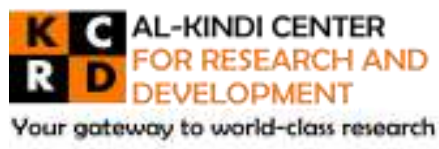

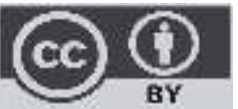

BY
Published by Al-Kindi Center for Research and Development, London, United Kingdom. Copyright (c) the author(s). This open access article is distributed under a Creative Commons Attribution (CC-BY) 4.0 license 
There is no standard definition of politics because it varies according to each setting, person and group involved. In the following pages, Chilton's definition of politics as "a struggle for power between those who seek to assert and maintain their power and those who seek to resist it" (2004: 3) is followed. In addition, Mazrui (1997:170) identifies politics as a "constant search for methods of resolving conflicting interests". Newmark (1986: 43-44) adds that "Politics" universally and generally is a human activity and tremendously, there is a reflection of politics in language. But, who is doing politics? The immediate answer is the politician.

Language can be put in an interdependency relationship with action and thought. The deepest part of language is to create social and political relationships. In some particular situations, language helps to evoke the roles of individuals who are involved in these relationships. On the other side, language also helps us depict the users' ideology (particularly politicians). The use of language in general and particularly in political discourse tells us about the ideas and the way by which these ideas have been shaped. More specifically, the use of language in the texts of politics helps us know about the ideologies of those who have been creating the texts (Beard, 2000:18).

The link between language and politics seems to be stated in the way that language and the manner it might be employed are deemed to be an instrument of politics. Any political actor who is involved in the field of politics employs much to attain a desire, influence or impression on their audiences. The field of politics is intertwined with every field of life, so that it seems to be very difficult to separate politics from language which forms it. In this respect, Spolsky (1998: 58) affirms that the language used in politics is inherently political. Political language represents different views, struggles, powers, opposing sides and interests. The utilization of language in the political field is that language can be exploited by individual politicians, groups with purposes, and the government to control, convince and apply power, etc.

From what has been stated above, it is obvious that language and politics cannot be effortlessly detached from one another, as they are strikingly interlinked. The area of "politics can be seen in every aspect of life, and thus, it comes to be inseparable from language itself". van Dijk (1997: 206) points to the idea that language and politics go together and politics failingly can be held without language, the case by which language use in the constitution of "social groups leads to what is called politics. In its wide sense."

\section{2- Critical Discourse Analysis}

The term critical discourse analysis first appeared at the beginning of the 1990s, engaging a small group of scholars participating in a symposium in Amsterdam, in 1991, including Teun van Dijk, Norman Fairclough, Gunter Kress, Theo van Leeuwen and Ruth Wodak. The researchers in critical discourse analysis began to publish in the Discourse and Society (1990) launched by van Dijk. During the years, many more journals followed, such as Critical Discourse Studies, The Journal of Language and Politics, etc., establishing the cultural discourse analysis as a per se paradigm in linguistics. Critical discourse analysis became a discipline included in the curricula and adopted as the main focus of research by many university departments worldwide (Wodak and Meyer, 2008:3).

As a school or paradigms, critical discourse analysis is guided by the following principles: problem-oriented, interdisciplinary and eclectic. Critical Discourse Analysis focuses on studying complex social phenomena and requires a multidisciplinary and multimethodic approach. Furthermore, critical discourse analysis focuses on the de-mystification of ideologies and power by investigating the semiotic data (Wodak, Meyer, 2008:2). (Wodak and Meyer, 2008). Contrary to discourse analysis, critical discourse analysis is more problem-oriented and interdisciplinary. It is important to emphasize the fact that "critical" does not necessarily mean negative but is mostly approached from another perspective.

CDA is not only descriptive but also interpretative and explicative in respect to the "relation between the form (i.e., grammar, morphology, semantics, syntax, and pragmatics) and the function (i.e., how people use language in different situations to achieve an aim) of language". According to Fairclough (1992a, 1995), critical requires an unsystematic approach, and being critical is supposed to create hidden "ideologies and interconnectedness of things visible through analysis", while criticizing the associations between "properties of texts and social processes, and power relations, which are not obvious to people who produce and interpret texts". Using this approach, critical discourse analysis loses its neutrality, exploring the unseen power in discourse in relation to wider social and cultural formations (Rogers, 2004).

One definition which is popular among the researchers is that: "critical discourse analysis sees discourse - language use in speech and writing - as a form of "social practice"s. Presenting discourse as "social practice implies a dialectical relationship between a particular discursive event and the situation(s), institution(s) and social structure(s) which frame it". The discursive action is shaped by them, but also shapes them. i.e, "discourse is socially constitutive as well as socially" conditions - it enunciates "situations, objects of knowledge, and the social identities of and relationships between people and groups of 
people. Discursive practices may have major ideological effects". In other words, they can "produce and reproduce unequal power relations" between social classes, women and men, and ethnic/cultural majorities and minorities through how they represent things and position people" (Fairclough and Woodak, 1997:258).

Understanding the term "critical" is based on the Critical Theory, which encompasses the totality of society in its historical specificity and helps understand society by integrating all the major social sciences. Critical discourse analysis aims to produce and deliver critical knowledge that can offer human beings the possibility for emancipation (Woodak, Mayer, 2008:7).

In sum, critical discourse analysis is often manipulated to attain the following aims:

i- CDA aims to make direct power relations that are usually beclouded and hidden and to determine results with practical importance.

ii- Since the approaches of CDA refer to extralinguistic factors such as culture, society and ideology, the concept of context is essential for CDA.

iii- CDA implements interdisciplinarity in different ways and uses concepts of intertextuality and interdiscursivity and analysis relationships with other texts.

iv- CDA does not consider the relationship between language and society as deterministic but refers to the idea of mediation.

v- most CDA researchers integrate linguistic categories into their analysis, but to a different extent, focus and intensity.

vi- CDA grounds itself in a wide range of theories such as epistemology, general social theories, middle-range theories, microsociological theories, socio-psychological theories, discourse theories and linguistic theories. Yet, it does not have a well-defined empirical method nor explain or recommend any data-gathering procedures. The methodology of CDA is more grounded on the hermeneutic tradition than in the analytical-deductive one. However, in what concerns the linguistic character of CDA, contrary to other approaches of text and discourse analysis, CDA relies on linguistic categories (Idem, 28).

\section{3- Political Discourse}

Political discourse is frequently seen as a highly specialized text form. This produces a problem in approaching a clear-cut definition of this linguistic variety because it seems to be constructed and manipulated in diverse ways according to the context and objectives involved. However, in his answer to the question about what constitutes political discourse, van Dijk offers the following interpretation:

"The easiest, and not altogether misguided, answer is that its actors or authors identify political discourse, viz., politicians. Indeed, the vast bulk of studies of political discourse is about the text and talk of professional politicians or political institutions, such as president and prime ministers and other members of government, parliament or political parties, both at the local, national and international levels" (van Dijk, 1997: 12).

Therefore, the definition of political discourse and confining it to the political talk, text and context with political aim and functions seem to be quite convincible. Van Dijk (ibid: 15) adds that to provide a satisfactory definition for the term "political discours", discourse should be identified in terms of its context, meaning, functions, aims, and goals which should primarily be political and not exclusively in terms of special practice and events. The notion of "political discourse" should be restricted to settings such as parliamentary proclamations, speeches and election campaigns and applied to all linguistic presentations that may be regarded as political (cf. Zheng 2000: 1).

Political discourse cooperates with all linguistic manifestations which are considered political. The context of socio-political sometimes affects discourse and changes it, so that Ruth Wodak (2009: 38-9) gives "four layers through which" one can discover "how genre, discourse and text" can be changed according to contexts of socio-political. (The term genre here means, as Fairclough, (1995: 14) describe, the way by which we use the language in an approved socially way in connection with a specific type of social performance).The four layers can be seen as it follows:

1- "The intertextual and interdiscursive relationships between utterances, texts, genres and discourses";

2- "The extra-linguistic social/sociological variables";

3- "The history and archaeology of texts and organizations"; and

4- "The institutional frames of the specific context of a situation". 
Taking into consideration the discourse of politicians, two ideologies have to be shown in their text: firstly, professional ideologies help politicians to attain their communicative functions, and secondly, the socio-political ideologies the politicians adhere to, e.g. members of parties (political parties) or social groups. Therefore, the combination and interaction of these ideologies in political discourse appear to be clear (Van Dijk, 1998a:15). Importantly, it is worth mentioning that political discourse includes not only political authors, but it also involves people as citizens of the country, people as members of issued groups and pressure, dissidents and demonstrators, and so on (Verba, et al., 1993: 303). Zheng (2000: 1) asserts that one of the characterizations of political discourse seems to be its ability to attractively the past and present. Hence, in some discourses studies, we can find a great impact of old "phraseology" and also "consciousness of precedent", by which relation to law or religion is displayed (ibid).

Political discourse provides a "coherent view of the nature of politics" which develops an obvious discrepancy between political discourse "and other sorts of discourse, or an agenda, a set of objectives, theoretical categories, and analysis methods". It enables principles of systematic evaluation (Isabela, 2012: 17). In this sense, political contexts are "institutional, i.e. contexts which make it possible for actors to exert their agency and empower them to act on the world in a way that has an impact on matters of common concern" (ibid).

\section{4- Racism}

In order to have a clear picture of what racism means, it is necessary to consider first the term race. In his book Racism after 'Race Relations', Miles points out that Race is a social constructional concept. Functionally, from a social angle, Race has been utilized as a "legitimising ideological tool". It is exploited to persecute an addressed group/s and to dispute them access to some social, cultural and political rights. It has been used by the affected groups as a basis for public (political) opposition and fighting for political autarchy, independence, and participation (1993: 28). Therefore, the term race has been adopted by these troubled groups.

Linguistically, there seems no crystalline etymological history of the term race. Therefore, very few words such as "razza", "raza", and "race" (respectively Italian, Spanish, Portuguese, and French) have been "documented from the thirteenth century" (Reisigl and Wodak, 2001: 2). However, at the beginning of the sixteenth century, the term appeared in English and entered different semantic fields (ibid). Among these fields is the one stated by Conze and Sommer (1984: 135), which involves such notions as referring to families of languages and language groups. According to Reisigl and Wodak, as far as we treat the constructed taxonomy of race (-as well as the related legitimation of racism) and the above mentioned semantic field as equivalent to language families, this can be the result of the fact that the linguistics and the contribution of ideology to philology were blameworthy (2001: 3). An important and striking fact to be mentioned here is that linguistics and philology appear to be responsible for some serious errors. These errors have built the basis for the approximation and the connection of language and race classification (Römer 1985: 41 ff.).

Focusing on politics, the race has become and/or merged with politics. By doing so, the concept has closely transferred to the terminologies of human history. "Race theorists interpreted history as a 'racial struggle' within which only the fittest 'races' would have the right to survive." (Reisigl and Wodak, 2001: 4). Historically, the 'antisemetic' term has appeared in Germany and Austria posters more than in the National Socialist reign of terror. The reason behind that goes for the fact that it has been considered a politically stigmatic word. Moreover, through history, its meaning has been broadened in the analysis of "anti-Jewish aggression" (ibid).

The creation and the birth of the two concepts, race and racism in Europe and North America, has gained its critical appraisal due to the Germanic antisemites and National Socialists' use of the theory of race (Miles, 1993: 29). Fleischer and Barz (1992: 190) perceive the term racism as a school of thought, doctrine or theory. This doctrine has been strictly tabooed for academics, the public and politicians in Austria and Germany.

The term 'racism' has been perceived in its strict sense by Albert Memmi (1992) as "a special variety of 'heterophobia', bearing a co-hyponymical relation to 'antisemitism' or 'Jewphobia', 'Arab-phobia', 'black-phobia', 'sexism', 'homophobia', 'youth-phobia' and 'phobia against differently-abled persons'" (Reisigl and Wodak, 2001: 5-6). By considering Colette Guillaumin (1991: 164; 1992) and Detlev Claussen (1994: 5), the term racism is considered as a "syncretism". It refers to the ideological muddle of different doctrines (pesudoscientific doctrines), beliefs (confessional beliefs) and religious beliefs. In signifies the views that construct a "pseudocausal" connections between symbolic, social, mental, phenotypic and fictitious traits. For Guillaumin the term means 1- a practical behaviour 2- a political program and 3- a practical horizon of state (Reisigl and Wodak, 2001: 6). On 
the other hand, Philomena Essed (1991 and 1992) points out that the term racism should be understood as "ideology, structure and process in which inequalities inherent in the wider social structure are related, in a deterministic way, to biological and cultural factors attributed to those who are seen as a different 'race' or 'ethnic group'" (Essed 1991: 43).

By looking into the term from another angle, Grosfouel (2011, as cited in Ramon Grosfoguel, 2016: 10) defines racism as a hierarchial global term of superiority and inferiority. This global hierarchy term exists among the line of humanity that has been expressed and reexpressed culturally, economically and politically by the institutions of the "capitalist/patriarchal westerncentric/Christian-centric modern/colonial world system". According to him, there are people above and below the line. Those who are above the line can enjoy their different rights starting from their human rights ending with their labor rights, while people below the line are taken as subhumans. In other words, their humanity is questioned and negated (Fanon (1967) as cited in Ramon Grosfoguel (ibid)). For example, different colonial histories seem to have different and diverse social markers through which interiority and superiority can be constructed. From another point of view, racism can be clearly marked by language, ethnicity, color, culture and religion (Grosfoguel, 2016: 10). The superiority in racism has been constructed through history by different groups. The third world westernized elites, for example, have practised racism against ethnic/racial groups; the British have reproduced racist practices against Irish in Irland's colonial history through religious markers (ibid: 10-11). Today's most prominent marker of superiority and interiority in Europe and in the United States is the Muslim religious identity. Muslims have been considered in Europe and North America as terrorists, violent, barbarians, etc. (ibid: 11).

As suggested by van Dijk, within many forms of public discourse, race relations and ethnic minorities can be seen as practiced by white people. Their daily communication acquires their "attitudes and the ideologies" that determine their actions and/or speeches against minorities. Therefore, the role of discourse is distinct in the production of racism and prejudice (1997: 31). In his study "Political Discourse and Racism: Describing Others in Western Parliaments", van Dijk points out that discourse plays a very important role on both levels, namely the micro and macro levels, as well as in both cognition and interaction roles. As a means of interaction, discourse may be discriminatory and this can happen when whites disvalue or derogate minorities. Moreover, some social cognitions such as ethnic prejudice can be influenced and expressed by discourse itself. On the other hand, at the macro level, discourse's genres or orders such as those of politics and media may be seen as "the overall manifestations of organizations or institutions in the system of ethnic-racial relations and as expressing the shared ideologies of the dominant white group". The power of the elite group (within the dominant white group) can be defined by their control and referential over the various form of public discourse. Thus, among such leading elites in society, politicians play a vital "role in a complex process in the definition of the ethnic situation" (ibid: 1997:33).

\section{5- Methodology}

The methodology of this paper involves two subdivisions. The first encompasses the method followed in data analysis and results analysis and the sample selected. The second comprises the proposed model for analysing the racist speeches in the selected data.

\subsection{Method and Sample}

The qualitative research method is used to describe and examine the selected data and gain results to account for the description and interpretation of the data and results analysis. The data are assembled from three political speeches given by Donald Trump.

\subsection{Model of Analysis}

Researchers and authors have drawn different approaches to analysing discourses in a critical way. Three inter-related processes have been adopted by Fairclough's $(1989,1995)$ to analyze discourse. These are: 1 - the verbal and visual texts i.e. the analysis's object, 2- writing/speaking/designing and reading/ listening/ viewing as processes by which human subjects produce and receive the object, 3- the "socio-historical conditions which govern these processes". In Fairclough's point of view, each of the above dimensions requires a specific kind of analysis, more specifically, descriptional analysis, interpretational analysis and explanation analysis. This approach has been considered as useful because it helps to provide "multiple points of analytic entry. It does not matter which kind of analysis one begins with, as long as in the end they are all included and are shown to be mutually explanatory". That is, it refers to "the interconnections that the analyst finds the interesting patterns and disjunctions that need to be described, interpreted and explained" (Janks, 1997: 329). Moreover, Fairclough (2003) takes into account Foucauldian's notion of discourse with a close focus on analysing the textual materials linguistically. In his attempt, Fairclough has developed linguistic means of analyzing structures and textual forms of discourse. However, the importance of this study lies in the idea that it can bridge the gap between the external social world (the world it tries to represent) and the structural form of language (Kazemian and Hashemi, 2014:1180).

On the other hand, van Dijk has considered the 'Socio-Cognitive Approach' in his study. It comprises three dimensions, namely the discourse, the cognitive and the social dimensions of analysis. In this approach, he has suggested some aspects (such as language use, discourse, verbal interaction and communication) of any social groups (some aspects which are related to the micro-level). Further, he points to other aspects related to the macro-level of the same group. These aspects are power, 
dominance and inequality. However, it should be mentioned that he applies his theory to media texts. In his attempt, he suggests having a link between discourse and society, i.e., between the micro and macro level. Along with what has been stated above, van Dijk gives ideology a specific emphasis because the concept of ideolgy is controlled by the group's social power (van Dijk, 2000).

In their book, 'Discourse and Discrimination', Reisigl and Wodak, (2001: 44) offer very useful analytical devices in analysing discourse about "ethnic, national and racial" issues. Their analytical tools are worthy of being used in this paper since the study seeks the use of 'racism' in discourse (more specifically, the political discourse). They pick up five rhetorical or linguistic means: someone is discriminated against racist manners or an ethnicist. The five discursive strategies used seem to be adopted to achieve particular psychological, linguistic, social or political aims. The five given discursive strategies of analysis are shown in the following table:

Table: Types of Discursivev Strategies (Reisigl and Wodak, 2001: 45).

\begin{tabular}{|c|c|}
\hline DISCURSIVE STRATEGIES & CHARACTERISTICS \\
\hline Referential or nomination strategies & $\begin{array}{l}\text { - represent social factors (ingroups and outgroups) } \\
\text { - realized in multiple ways, with reference by tropes, biological, } \\
\text { naturalizing and depersonalizing metaphors, metonymies and } \\
\text { synecdoches }\end{array}$ \\
\hline Predicational strategies & $\begin{array}{l}\text { - realized as stereotypical, evaluative attribution of negative and } \\
\text { positive traits in the linguistic form of implicit or explicit predicates } \\
\text { - aim at labelling social actors either in a positive or negative way } \\
\text { - they are connected with nomination strategies }\end{array}$ \\
\hline Argumentation strategies & - the justification of positive or negative attributes \\
\hline $\begin{array}{l}\text { Perspectivation, framing or discourse } \\
\text { representation strategies }\end{array}$ & $\begin{array}{l}\text { - the speakers express their involvement in the discourse and } \\
\text { express their point of view }\end{array}$ \\
\hline Intensifying and mitigation strategies & $\begin{array}{l}\text { - the qualification and modification of the epistemic status of a } \\
\text { proposition by intensifying or mitigating the illocutionary force }\end{array}$ \\
\hline
\end{tabular}

\section{6- Data Analysis}

For the purpose of the present paper, we have selected three political texts given by the former president of the United States of America, Donald Trump. Trump started his presidential campaign from the Trump Tower in Manhattan. Having a slogan during the campaign, "Make America Great Again", one of the issues on his political agenda was (illegal) immigration. Some of his comments, however were touched by racism, as resulted from the following statements:

1- "When Mexico sends its people, they're not sending their best. They're not sending you. They're sending people that have lots of problems, and they're bringing those problems with us. They're bringing drugs. They're bringing crime. They're rapists. And some, I assume, are good people," Trump said at his campaign announcement. "But I speak to border guards and they tell us what we're getting. And it only makes common sense. It only makes common sense. They're sending us not the right people. It's coming from more than Mexico. It's coming from all over South and Latin America, and it's probably coming from the Middle East. But we don't know. Because we have no protection and we have no competence, we don't know what's happening. And it's got to stop and it's got to stop fast." (https://www.politico.eu/article/15-most-offensive-things-trump-campaign-feminism-migration-racism/)

Through his comment, he tends to generalize a negative trait of the Mexican people and Latinos generally, extending his view that immigration law allows access to the USA to those coming from border and from far countries.

Analyzing this statement based on the discursive strategies proposed by Reisigl and Wodak, the use of the following types of discursive strategies can be identified:

- predicational strategies

- perspectivation, framing or discourse representation strategies

a) Predicational strategies - these strategies imply realizing stereotypical, evaluative attribution of negative and positive traits in the linguistic form of implicit or explicit predicate and aim at labelling social actors in either a positive or negative way.

In our fragment, as a social actor, we identify the immigrants coming from Mexico and Latin America, which are labelled negatively, explicitly. In his description of the Latino immigrants, through adjectives such us "rapists", "not their best", "not the 
right people", Trump leads to a generalization of this social actor, leading to a stereotypical description of it. Furthermore, through the verb " bring" in present continuous followed by nouns with negative connotation "problems", "crimes", "drugs", Trump implies that the entire group is represented by individuals who, through their continuous actions, generate the increase of delinquency rate in the USA.

b) Perspectivation, framing or discourse representation strategies - these strategies imply that the speakers express their involvement in the discourse and express their point of view.

The excerpt shows that the discourse is made only from the speaker's point of view who does not bring any official date to sustain his argument, except his involvement. By using the personal pronoun "I (speak)", it becomes obvious that the speaker expresses his direct involvement in the discourse and by using the personal pronoun "I assume" it shows that the statement is made from his own point of view. The uncertainty of his statement is confirmed by the use of the adverb "probably", which is repeated two times. However, despite the fact that he does not have official and confirmed data, he tends to generalize the characterization of the group not only to Mexican citizens, but to those coming from Latin America and Middle East. However, by changing the subject from first person singular (I) to first person plural (we), he tries to share the responsibility of the fact that the information it is not certain or confirmed (But we do not know). He ends his statement by completely delimiting himself to any responsibility of stopping the (illegal) immigration by depersonalizing the subject ("And it's got to stop and it's got to stop fast").

\section{2- "Black guys counting my money! I hate it. The only kind of people I want counting my money are short guys that wear yarmulkes every day. I think the guy is lazy. And it's probably not his fault because laziness is a trait in blacks. It really is, I believe that. It's not anything they can control." https://www.politico.eu/article/15-most-offensive-things-trump- campaign-feminism-migration-racism/}

The above speech presents us, in our opinion, elements of a racist speech. Analyzing this statement based on the discursive strategies proposed by Reisigl and Wodak, we can identify the use of the following types of discursive strategies:

- perspectivation, framing or discourse representation strategies

- predicational strategies

- referential strategies

- argumentation strategies

a- Similar to the first extract, we can realize the speaker's involvement and point of view in the text stated above in this fragment. In other words, by reading the excerpt, we can infer that the speaker has stated his view towards the blacks. Trump involvement is based on non-official facts towards black. From another perspective, the speaker gives his direct involvement by saying "I hate it", "I think the guy is lazy", "I believe that". The use of the personal pronoun has given no choice to consider Trump's words as based on general facts. Closely examining his words, we can prove that Trump's racist remark has been generalized to cover all blacks, not only the ones working in his Hotel or Casino. By saing "And it's probably not his fault because laziness is a trait in blacks.", Trump again tries to generalize the trait of laziness to all blacks which he continues to assert by saying "It really is, I believe that". Moreover, Trump ends up his words by sending an indirect message, saying "It's not anything they can control" which has pragmatic information that demands hearers to encode it, namely that to stop giving blacks jobs.

b- By reading the above fragment, we can deduce that the speaker has given a negative trait that can be realized as a stereotypical attribution in a straightforward way. In other words, from the speaker's words, we can identify his remark of "laziness" towards all black people. Therefore, his use of such adjective "laziness"and the asserted statements "It really is" I believe that." which belong to the previous remarks "laziness is a trait in blacks" have made it clear that Trump is trying to generalize this social trait to all blacks. Along with the above given negative trait, Trump refers to another stereotypical description but positively according to his view. Trump tries to present Jews as good as always with money. He refers to the kind of people he wants to count his money as wearing "yarmulkes"; the term can refer to Jews who are wearing it on their heads. In other words, the speaker tries to express a positive stereotypical attribution in an explicit way. Therefore, by saying "The only kind of people I want counting my money are short guys that wear yarmulkes every day", he tries to make an exception "The only kind of people" to those who are allowed to count his money by identifying them as good and trusted.

c- In the above text, the speaker gives his words with reference to a biological fact. In other words, he uses the word "black" in accordance with the adjective "laziness". However, this can imply that the speaker is trying to state a kind of semantic entailment. From another angle, whenever there is a black worker, that entails there is laziness. It should be mentioned here that blackness is 
not the fault of the people. They are black by their biological state and/or body. Therefore, this can be seen as another strategy of using racist remarks.

d- In relation to the previous proposed point, the two words "black and laziness" can not be controlled by nature. Because blackness is a biological matter and being lazy, something tends to be a trait of some people. Therefore, the speaker's use of the negative attribute "laziness" as a generalized trait of "blacks" seems to be incorrect. In other words, the speaker has given an argumentational strategy by stating, "Black guys counting my money! I hate it. The only kind of people I want counting my money are short guys that wear yarmulkes every day. I think the guy is lazy. And it's probably not his fault because laziness is a trait in blacks. It really is, I believe that. It's not anything they can control."

\section{3- "Negotiating with Japan, negotiating with China, when these people walk into the room, they don't say, 'Oh, hello, how's the weather, so beautiful outside, isn't it lovely? How are the Yankees doing? https://www.tnp.sg/news/world- news/donald-trump-mocks-chinese-businessmen-broken-english}

As was said, Donald Trump was giving an anecdote during a campaign rally in Lowa when he started to describe the difference between the American way and the Chinese/Japanese way of negotiation deals. Unlike Americans, Chinese and Japanese did not bother themselves with the niceties at meetings.

The fragment has been considered as having racist remarks. By reading the text carefully, we can refer to the stereotypical strategy which Trump has tackled while describing Chinese and Japanese.

The speaker refers to a stereotypical strategy with which he uses some words and expressions to describe Chinese and Japanese. In other words, Trump identifies some traits in the linguistic form of explicit and implicit predicates. By saying "when these people walk into the room, they don't say, 'Oh, hello, how's the weather, so beautiful outside, isn't it lovely? How are the Yankees doing?". This fragment can be understood in two ways. The first interpretation of Trump's words is that he tries to encircle Chinese and Japanese with the lack of manner, lack of behaviour and lack of education, such as saying hello, inquiring or describing the weather etc. Therefore, from his speech, we can say, it is a direct realization of negative traits to describe Chinese and Japanese and an indirect realization of the positive traits of Americans. From another view, contrary to Chinese and Japanese, by saying the above words, Trump was trying to refer indirectly to the good traits that Americans and Europeans have. However, it can be said that Trump has given his speech in order to label Chinese and Japanese in a negative way. The second way to understand his words is that he tries to emphasize the direct way of the Asian people to do business. Compared to Europeans, which are spending more time with social interaction before going to the subject, Asians tend to prioritize the business matters on hand and deal later with the social interaction.

\section{7- Conclusion}

Based on the above analysis, the present study arrives at the following conclusions:

The use of racism has been expressed explicitly and implicitly through adjectives and nouns, such as rapist, problems, drugs, crime, black, and laziness. For example, in some texts, texts 1 and 2, the speaker indirectly generalizes the negative idea and extends it towards all the people who share the same trait. Besides, through the use of negative traits, the speaker tries to express a positive attitude to some others, such as the Jews and the Americans. Based on the strategies of analysis, the study shows that Trump's use of racist speeches reflects his subjectivity. In other words, it reflects only his point of view because there seems to be no official date to sustain the arguments given by him. Predicational, perspectivational, stereotypical description and argumentation strategies are the ones used by Trump towards others.

In accordance with this study's findings, the researchers recommend that more studies on CDA and semiotics of political discourse are required to uncover Western and Eastern politicians' hidden ideologies and powers as these concepts are closely related to sociopolitical perspectives.

\section{References}

[1] Beard, A. (2000). The Language of politics. London: Routledge,.

[2] Claussen, D. (1994). Was heißt Rassismus?, Darmstadt: Wissenschaftliche Buchgesellschaft.

[3] Conze, W. and Sommer, A. (1984) 'Rasse', in: O. Brunner, W. Conze and R. Koselleck (eds) Geschichtliche Grundbegriffe: Historisches Lexikon zur politisch-sozialen Sprache in Deutschland, Stuttgart: Klett-Cotta. Vol. 5: Pro-Soz, pp. 135-77.

[4] Crystal, D. (1995). The Cambridge Encyclopedia of the English Language, 2nd ed. Cambridge: Cambridge University Press.

[5] Essed, P. (1991). Understanding Everyday Racism: An Interdisciplinary Theory, London: Sage. 
[6] Essed, P. (1992). 'Multikulturalismus und kultureller Rassismus in den Niederlanden', in: Institut für Migration und Rassismusforschung e.V. (ed.) Rassismus und Migration in Europa: Beiträge des Kongresses 'Migration und Rassismus in Europa' Hamburg, 26. bis 30. September 1990, Hamburg and Berlin: Argument, pp. 373-87.

[7] Fairclough, N. (1989). Language and Power. London: Longman.

[8] Fairclough, N. (1992). Discourse and Social Change, Oxford: Polity Press/Blackwell.

[9] Fairclough, N. (1995a). Critical Discourse Analysis: The Critical Study of Language, London: Longman.

[10] Fairclough, N. \& Wodak, R. (1997). 'Critical discourse analysis'. in: van Dijk, Teun A. (Ed.) Discourse as Social Interaction. London: Sage, pp. 258-284.

[11] Fairclough, I. and Fairclough, N. (2012). Political Discourse Analysis: A Method for Advanced Students. New York: Routledge.

[12] Fleischer, W. and Barz, I. (1992). Wortbildung der Deutschen Gegenwartssprache, Tübingen: Niemeyer.

[13] Grosfoguel, R. (2016). What is Racism?. Journal of World-Systems Research, 22(1), 9-15.

[14] Guillaumin, C. (1991) 'RASSE: Das Wort und die Vorstellung', in: U. Bielefeld (ed.) Das Eigene und das Fremde: Neuer Rassismus in der Alten Welt. Hamburg: Junius, pp. 159-73.

[15] Guillaumin, C. (1992) 'Zur Bedeutung des Begriffs "Rasse" ', in: Institut für Migration und Rassismusforschung e.V. (ed.) Rassismus und Migration in Europa: Beiträge des Kongresses 'Migration und Rassismus in Europa'.Hamburg, 26. bis 30, pp. 77-87.

[16] Janks, Hilary. "Critical Discourse Analysis as a Research Tool" in Discourse: Studies in the Cultural Politics of Education. Vol/ 18 (3) (1997): 329-342.

[17] Kazemian, Bahram, Hashemi, Somayyeh (2014) "Critical Discourse Analysis of Barack Obama's 2012 Speeches: Views from Systemic Functional Linguistics and Rhetoric" in Theory and Practice in Language Studies, vol 4, pp.1178-1187.

[18] Mazrui, A. A. (1997): "Islamic Values, the Liberal Ethic and the West." in Foreign Affairs. Vol/ 76, (No) (118-132).

[19] Memmi, A. (1992). Rassismus. Hamburg: Europäische Verlagsanstalt.

[20] Miles, R. (1993). Racism after 'Race Relations'. London: Routledge.

[21] Newmark, P. (1983). "The translation of Political Language". in: Dimensioni linguistiche e distanze culturali nell'interazione sociale e politica, atti del convegno, Trieste, 28-29Trieste: EUT Edizioni Università di Trieste (1986): 43-64.

[22] Oliver, M. (1994). "Politics and Language: Understanding the Disability Discourse." Paper prepared for inclusion in the MA in Disability Studies Programme: Dept. of Psychotherapy, University of Sheffield, Available online at: http://www.leeds.ac.uk./disabilitystudies/archiveuk/Oliver/pol\%2094-pdf.

[23] Reisigl, M. and Wodak, R. (2001). Discourse and Discrimination: Rhetorics of Racism and Antisemitism. London: Routledge.

[24] Rogers, R. (Ed.). (2004). An introduction to critical discourse analysis in education. Lawrence Erlbaum Associates Publishers.

[25] Römer, R. (1989). Sprachwissenschaft und Rassenideologie in Deutschland. Munich: Fink.

[26] Spolsky, B. (1998). Sociolinguistics. Oxford University Press,

[27] van Dijk, T. (1990). 'Social cognition and discourse', in: H. Giles and W. P. Robinson (eds) Handbook of Language and Social Psychology, Chichester: John Wiley and Sons, pp. 163-86.

[28] van Dijk, T, (2000). 'Critical discourse analysis', in: D. Tannen, D. Schiffrin and H. Hamilton (eds) Handbook of Discourse Analysis, Oxford: Blackwell.

[29] van Dijk, T., Ting-Toomey, S., Smitherman, G. and Troutman, D. (1997) 'Discourse, ethnicity, culture and racism', in: T. van Dijk (ed.) Discourse as Social Interaction. London: Sage, pp. 144-80.

[30] van Dijk, T. (1998a). 'Context models in discourse processing', in: H. Oostendorp and S. Goldman (eds) The Construction of Mental Models during Reading. Mahwah, NJ: Erlbaum, pp. 123-48.

[31] Verba, Sidney. Schlozman, Kay. Brady, Henry., and Nie, Norman. "Citizen Activity: Who Participates: What Do They Say." in American Political Science Review. Vol/87(2), (1993): 303-318.

[32] Wodak, Ruth, Meyer, Michael (2008). "Critical Discourse Analysis: History, Agenda, Theory, and Methodology" inWodak, Ruth, Meyer, Michael (eds) Methods of Critical Discourse Analysis, Second Edition, Sage Publication.

[33] Wodak, R. (2009). The Discourse of Politics in Action. Chippenham and Eastbourne: CPI Antony Rowe,

[34] Zheng, T. (2000)."Characteristics of Australian Political Language Rhetoric: Tactics of Gaining Public support and Shrinking Responsibility". Journal of Intercultural Communication, http://www.immi.se/intercultural/nr4/zheng.htm. 